\title{
Influence of Training on Employees Performance in Public Institution in Tanzania
}

\author{
Elizabeth Landa \\ School of Public Administration and Management \\ Mzumbe University \\ P.o Box 2, Mzumbe, Morogoro, Tanzania
}

Received: April 7, 2018 Accepted: April 27, 2018 Online published: May 13, 2018

doi:10.5296/ijhrs.v8i2.13136 URL: https://doi.org/10.5296/ijhrs.v8i2.13136

\begin{abstract}
This study aimed at examining the influence of training on employees' performance; it involved a case study design where Tanga Urban Water Supply and Sewerage Authority (Tanga UWASA) was selected. Stratified Random sampling and purposive sampling techniques were used to select a sample of 71 respondents for the study. Respondents were chosen from ordinary employees, heads of departments and the management of Tanga UWASA. Data were collected using interview, questionnaires and documentary review. Quantitative data were analyzed using Statistical Package for Social Sciences (SPSS) to yield descriptive statistics such as frequency and percentages while Chi square was used to determine influence of training on employee perfomance. Qualitative data were analysed using content analysis. The findings indicated that Tanga UWASA organises several training programmes and employees are systematically selected to attend those programmes to acquire knowledge and skills. On the other hand, the study found that training has significant influence on employee performance. This relationship was found statistically significant at $\mathrm{P}$ $<0.05$. The more the employee gets training, the more efficient their level of performance would be. Training programmes contributed to the increase of efficiency, productivity, rise of customers' level of satisfaction and the increase of Tanga UWASA's competitive advantage over other water supply authorities.
\end{abstract}

Keywords: training, employees, performance, Tanga-UWASA

\section{Introduction}

Due to fast pace global and technological development; organizations are now facing new changes and challenges which molded capabilities and competencies required to perform certain tasks. Training seen as a useful means of coping with those changes fostered by 
technological innovation, market competition, and increasing productivity (Bhatt, 2013 ).Thus all organizations irrespective of size and market, strive to improve the performance of the employees through different strategies among others off the job \&on the job training (Meyer \& Smith 2000). Training is very important tool for an organization to compete in a changing and challenging world (Raja, Furqan \& Muhammad, 2011).Training is done when there are indicators for training need as indicated by production records ,number of accident, mistakes ,expansion of operations ,inversion of new technology ,employees turnover ,promotions and transfer (Graham \& Bennett, 1991). The need for staff training is accelerated by the gap between the actual performance of the employee with the desired performance required by the organization.

In order to prepare workers to do their job as desired, organizations provide training as to optimize their employees' potential. Most of the firms, by applying long term planning, invest in building new skills of their employees, enabling them to cope with the uncertain conditions that they may face in future thus improving their performance. Therefore, equipping these unique assets with effective training becomes imperative for improving organizational performance. Once a training program is completed, worker's productivity is expected to increase. The benefit will be to the organization due to an increase in workers' output and productivity and to the workers, as the increase in output should translate into higher wages and opportunities for career advancement (Wei-Tai, 2006).

Despite the effort done by organizations currently in offering training to its staff through monies devoted by the government; Yet presently many complains have been directed to public sectors workers for ineffectiveness and inefficiency ( URT, 2013).Training for public sector employees has been seen as revenue user and not producer and a total loss of government funds. As most of researches base on assessing effectiveness of training programs, training policies, training methods and other factors that affects employee training in organization as it has been reflected in their researches to mention a few, (Waziri\& Stephen, 2013).This study is interested to examine the influence of training on employee performance and hence provide training related recommendations for uncalled poor performance in public organizations.

\section{Literature Review}

\subsection{Concept of Training}

Training is the method used to give employees skills and knowledge they need to perform their jobs (Dessler, 2005). (De Cenzo \& Robbins, 1996) defined training as learning experience which seeks a relatively permanent change in an individual to improve that individual's ability to perform his or her job effectively.

Training may in other way mean changing what employees know, how they work, their attitude towards work, or their interaction with their co-workers or supervisors. In fact, there is a correlation between training expenditures of an organization and economic performance measures, such as return on assets and productivity, service delivery. However, it was argued that the fourth 'results' level is only assessing the non-economic impact of training such as 


\section{Macrothink}

International Journal of Human Resource Studies

ISSN 2162-3058 2018, Vol. 8, No. 2

employees' morale, learning, behavioural change and transfer of learning, and even assessing the intangible economic results within an organisation (Hamblin, 1974; Reid \& Barrington, 2003).

\subsection{Systematic Approach to Training}

Training should be systematic, that is specifically designed, planned and implemented to meet defined needs. It is provided by people who know how to train and the impact of training is carefully evaluated (Armstrong, 2006). Most of the benefits derived from training are easily attained when training is planned. This means that the organization, trainers and trainees are prepared for the training well in advance (Nassazi, 2013).

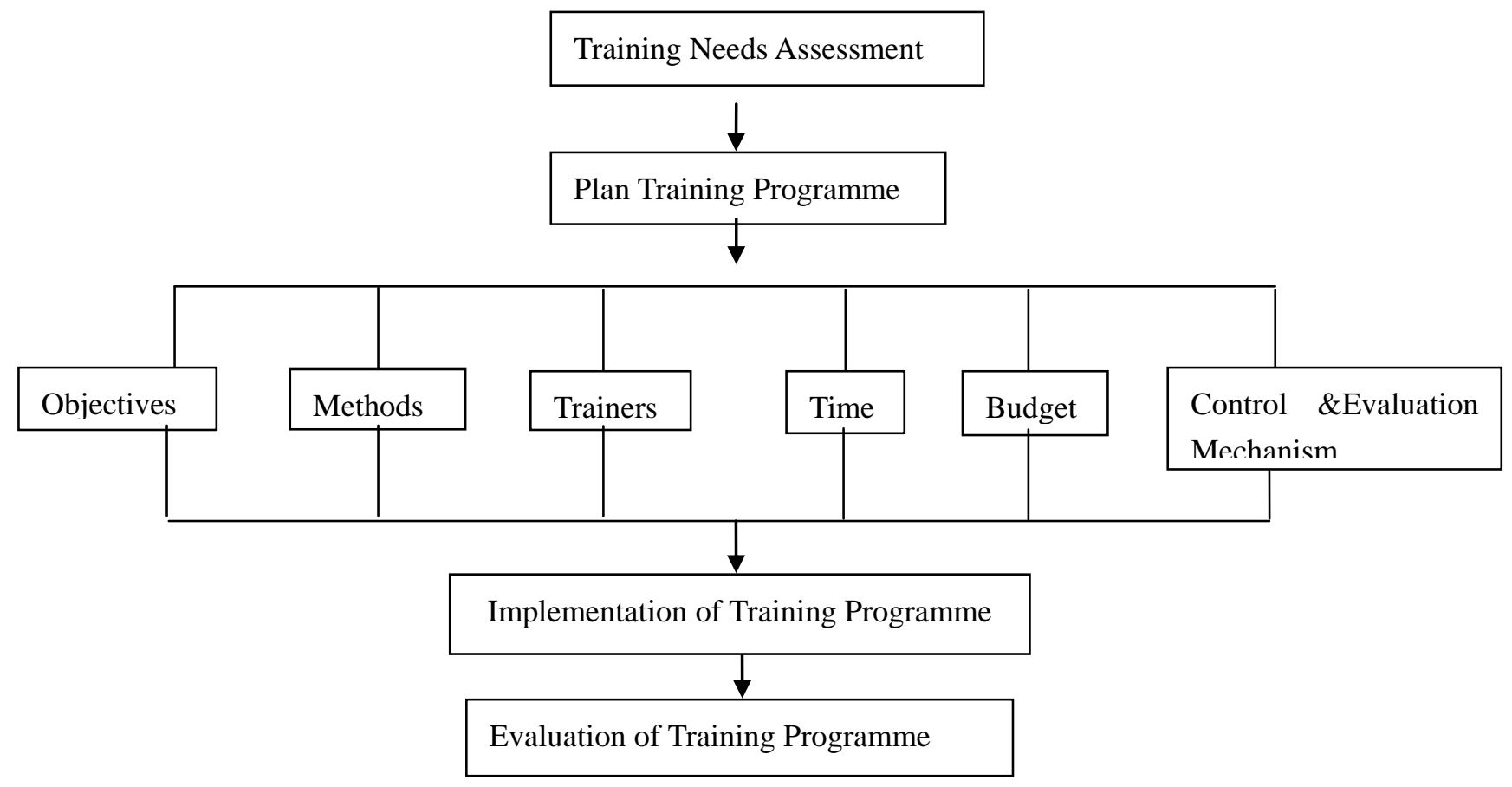

Figure 1. Systematic approach to training programs as modified from Armstrong (2006)

\subsection{Training Influence on Employee Performance}

(Nassazi ,2013) noted that, training has been proved to generate performance improvement for the employee as well as for the organization by positively influencing employee performance through the development of employee knowledge, skills, ability, competencies and behavior (Appiah, 2010). (Ngwira, 2009) elaborates on training as a means of dealing with skill deficits and performance gaps as a means of improving employee performance. According to him, bridging the performance gap refers to implementing relevant training intervention for the sake of developing particular skills and abilities of the employees and enhancing employee performance. He further elaborated the concept by stating that training facilitate organization to recognize that its workers are underperforming and thus their knowledge, skills and attitudes needs to be molded according to the firm needs. ( Gray ,2004) explained that through training the employee competencies are developed and enable them to implement job related work efficiently, and achieve firm objectives in a competitive manner. 


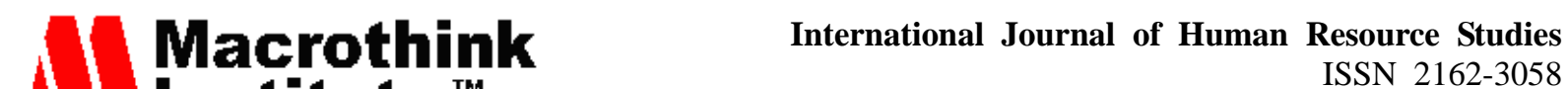 2018, Vol. 8, No. 2}

\subsection{Empirical Studies on Training and Employees' Performance}

Increasing employees' performance through training has becoming a big deal and more popular issue among policy makers, academics and management practitioners. Apart from adding value to organization operations, training as management strategy could generate income to employees. Recognizing these benefits, scholars came up with many studies concentrate on training and performance. For example, (Benabou 1996) examined the impact of various training programmes on the business and financial results at 50 Canadian organizations. The conclusion reached was that in most cases a well designed training programme can be linked to improvements in business results and that return on investment in training programmes is very high. A national survey of training evaluation in specialized healthcare organizations (hospices) conducted by (Clarke ,2004) showed that while there appeared to be some links between training and performance it was not possible to reach firm conclusions about causality. However, the study reached the important finding that where organizations undertake assessment of their training and development (both formal and informal learning) then there is a greater belief in the positive impact training and development has in the organization.

Much of literature in Africa focus on the link between the variables prescribed; (Odinga, 2010) conducted a study on staff development programs and job performance of Lecturers of Moi University (Kenya). The Pearson's Linear Correlation co-efficient between training and job performance of Lecturers was 0.541 meaning that there was strong positive correlation between training and job performance (as training increases, lecturers' job performance increases). These results are likely the same as of (Degraft, 2012) who researched on the effect of training and development on employees' performance at Accra Polytechnic (Ghana). The results found that, majority agreed that training has excellent impact on their performance. This implies that training has adversely impacts on employees' performance.

In Tanzania, (Mwambe, 2010) conducted a study on the assessing the influence of training on employees' performance in higher learning institutions (CBE), majority argued that training increased their capacities to adopt new technologies and methods, sharpened their mental capacity that enhanced their performance and assisted them to establish clear views of their work roles. 
Conceptual Framework

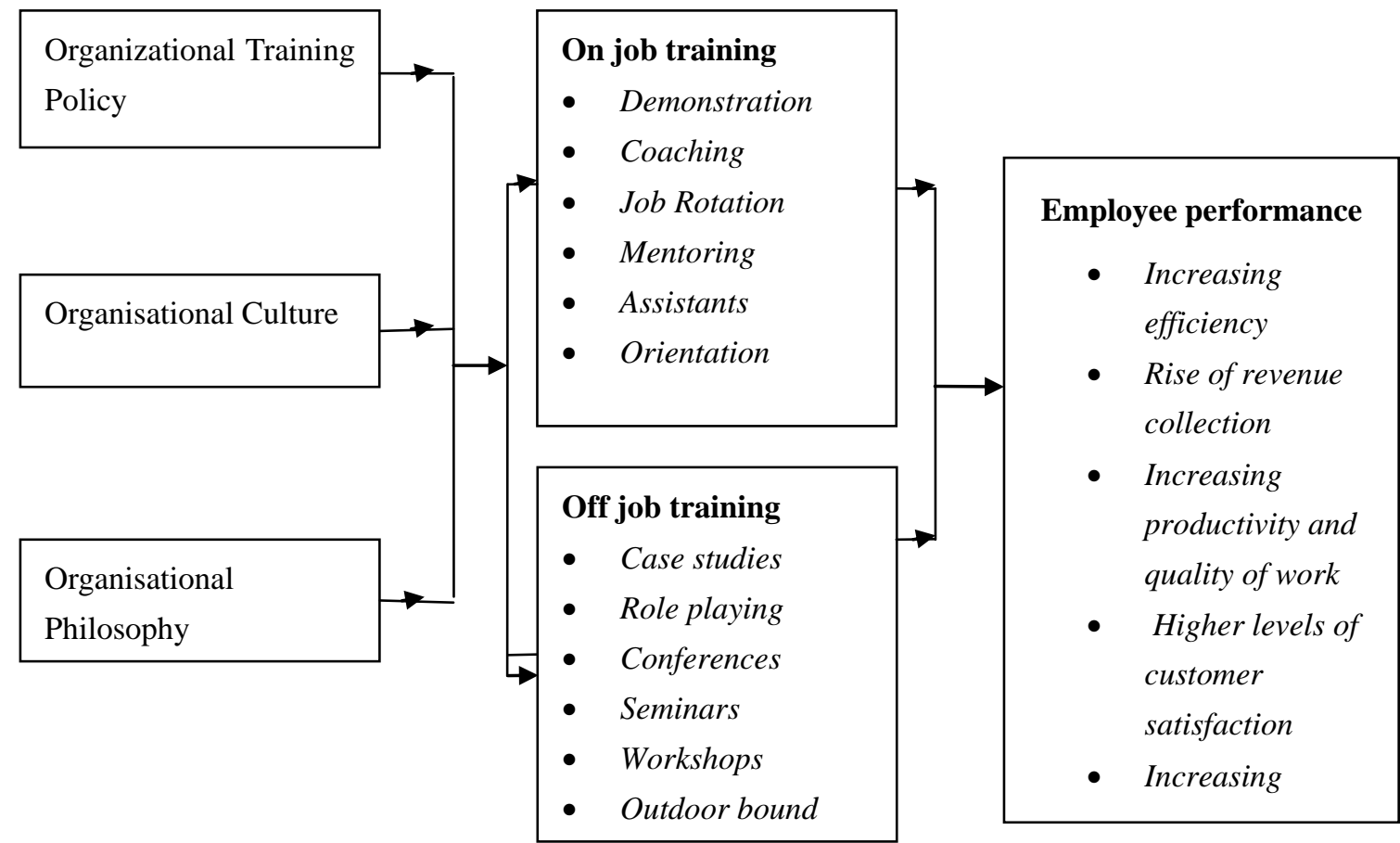

Figure 2. A framework shows the relationship between Training and Performance

\section{Synthesis}

This study treats employees' performance as dependent variable and training as independent variable ceteris peribus. Basing on the review of the theoretical and empirical literatures, it has been observed that there is a positive influence of training on employees' performance. The existence of training policy, organization culture and organizational philosophy in the Public Institutions acts as a catalyst to implementation of training programmes effectively.

\section{Method}

This study was conducted at Tanga Urban Water Supply and Sanitation Authority(Tanga UWASA) in Tanga region since it was reported that Tanga UWASA stands as the best of all urban water and sewerage authorities in Tanzania on provision of water supply services (URT, 2014). A mixed method research design was adopted where a combination of quantitative and qualitative research methods was used in order to minimize bias associated with using a single method. (Creswell 2003; Glazier \& Powel; 1992). Quantitative data were gathered using a questionnaire administered to 71 respondents while qualitative data were gathered using guided questions for interviews with key informants (the MD, HR-M\&HR-O) who were purposively selected due to their roles regarding decision making on matters relating to training at Tanga UWASA. A sample size of 71 respondents were used out of 148 population as advised by (Sekeran, 2007) that too large sample size could become problem and recommended sample size is between 30 to 500 respondents. The influence of training on employee performance has 9 items. Scholars suggests that a value of 0.7 to 0.8 is an 
acceptable value for Cronbach's alpha (Pallant, 2007; Field, 2009). The Cronbach's alpha for influence of training on employee performance scale in this study was 0.74 , which indicates that the research instrument was reliable.

The overall scores on the Likert scale were categorized into low, medium and high perception of an employee on improving performance. The highest possible score was calculated by multiplying 9 statements by 5 points to get 45 points; while the middle point was calculated by multiplying 9 statements with 3 points to get 27 points, and the lowest possible score was calculated by multiplying 9 statements by 1 point to get 9 points. Therefore, 27 was the cut-off point and stood for medium. Hence, scores from 9 to 26 on the overall scores were considered as low attitude; while 28 to 45 stood for High. The study employed chi-square test to determine the influence of Training on Employees Performance.

\section{Results and Discussion}

\subsection{Training Programme Attendance}

The study strived to examine employees' training attendance at Tanga UWASA. The in depth interview revealed that majority of employees at Tanga UWASA have been attending training. One of respondents interviewed revealed that:

"Almost all our employees have attended training programs; some have attended more than thrice. When an employee is recruited in our organisation is attending orientation and job instruction training, and then when working for a given period of time we measure his or her performance for further training"

Also, the respondents were given categorical questions to answer on to whether they have been attending training or not.The results in table 1 indicates that majority $81.7 \%$ of respondents have attended training at Tanga UWASA.

Table 1. Employees Training Attendance

\begin{tabular}{lcc}
\hline Response & Frequency & Percent \\
\hline Yes & 58 & 81.7 \\
No & 13 & 18.3 \\
Total & $\mathbf{7 1}$ & $\mathbf{1 0 0}$ \\
\hline
\end{tabular}

The findings revealed that majority of respondents involved in the study have attended training programmes at Tanga UWASA. The findings imply that Tanga UWASA might have improved its performance and raises job satisfaction of employees, since training provides new knowledge and skills which in turn improve the organisational performance. Similar observation was done by (McKinsey, 2006), who argued that employee training is important in any organization throughout the world, due to its active role in raising employee job satisfaction and improving organisational performance. Also, (Scopo, 1970)as noted by Armstrong, argued that training is one of the tools for enhancement of effective performance in the organisation. 


\subsection{Kinds of Training Programmes Attended by Employees}

The study seeks to ask respondents on the kinds of training programm attended which were categorized into three; Job training programme, Academic training programme and Study tour. Key informants reported that:

"Tanga UWASA has been organizing several kinds of on and off the job trainings such as orientation programmes, tailor-made programmes,workshops, job rotation, academic/professional programmes, study tours and distance learning."

Moreover, the data collected through documentary review particularly from Tanga UWASA Training Policy showed that training which shall be provided by the authority is grouped into main four categories, namely; orientation/induction/internship training, tailor-made training programmes, academic/professional programmes, study tours and distance learning. The policy goes further by explaining the purpose of programmes, how each training programmes will be conducted and targeted trainees, foristance; Orientation / Induction / Internship training shall be conducted to newly recruited employees and other sole business partners, such as suppliers, contractors to mention a few. It shall aim at transferring the culture of doing things in perspectives of the Tanga UWASA. Meanwhile it was discovered that tailor-made training courses mean to refresh the respective training recipients (who are the normal employees of the Tanga UWASA) on new or improved techniques of doing things.

The questionnaire data revealed that 51 which is $71.8 \%$ respondents attended job training programmes, 5 respondents which is $7 \%$ attended academic training programmes, 1 respondent which is $1.4 \%$ attended training through study tour. 14 respondents which is $19.7 \%$ replied on other training as shown in Table 2.

Table 2. Employees' Training Programmes at Tanga UWASA

\begin{tabular}{lll}
\hline Types of training & Frequency & Percent \\
\hline Job training & 51 & 71.8 \\
Academic training & 5 & 7.0 \\
Study tour & 1 & 1.4 \\
Other training programmes & 14 & 19.7 \\
Total & $\mathbf{7 1}$ & $\mathbf{1 0 0 . 0 0}$ \\
\hline
\end{tabular}

The findings of the study revealed that Tanga UWASA is mostly conducting job training programmes for its employees. The findings imply that Tanga UWASA could be one of the Urban Water and Sewerage Authorities in Tanzania which had improved its performance due to training, as argued by (Joshi, 2013) that the purpose of job training is to increase the knowledge of workers about the jobs with which they are concerned so that their efficiency and skills of performance are improved. Also the observation is consistent with EWURA's Water Utilities Performance Review Report of 2013/2014 which shows that Tanga UWASA is the best of all Urban Water and Sewerage Authorities in Tanzania on provision of water supply services (URT, 2014).

\subsection{The Extent to Which Training Influences Employees'Performance}

Training has been proved to generate performance improvement related benefits for the 
employee as well as for the organization by positively influencing employee performance through the development of employee knowledge, skills, ability, competencies and behavior as noted by (Nassazi, 2013). This part sought to examine the influence of training on employees' performance. To support this objective, the study investigated the relevance between training programmes attended by respondents to their job roles and then 5 points likert scale used to study sub themes of the training influence on employee performance at Tanga UWASA whereby respondents who have been attended training in one way or another were provided with the table containing statements showing the influence of training on employees' performance and they had to tick whether they are strongly agree, agree, neutral, strongly disagree or disagree to the statements provided.

\subsubsection{Relevance of Training Programme to the Job Roles}

The study strived to examine whether the training programmes conducted at Tanga UWASA were relevant to job roles. In depth interview revealed that training programmes which have been attended by employees are relevant with the job roles in the authority. During key informant discussions at Tanga UWASA it was revealed that Before conducting training, Training Need Analysis (TNA) is done, this made an assurance that trainings conducted are relevant to the need of the organization

On the other hand the study findings indicated that $71.8 \%$ of respondents agreed that the training programmes conducted at Tanga UWASA are relevant to the employee's job roles (Table 3.).

Table 3. Relevance between Training Programme and Job Roles

\begin{tabular}{lcc}
\hline Response & Frequency & Percent $(\%)$ \\
\hline Yes & 51 & 71.8 \\
No & 7 & 9.9 \\
I don't Know & 13 & 18.3 \\
Total & $\mathbf{7 1}$ & $\mathbf{1 0 0}$ \\
\hline
\end{tabular}

It was evidenced that employees at Tanga UWASA have been provided with relevant training to employees' job roles. The findings are consistent with (Winterton, 2007), who argue that the objective of training is to ensure that all employees have and maintain the requisite competences to perform in their roles at work. This is attained when training programme is relevant to trainees' roles and has objectives which are relevant. However, the relevance between training programmes and job roles can be attained if the programmes have been well designed, planned and implemented as argued by (Aswathappa, 2014) that training and development programme have to follow a series of four stages namely; training need assessment which involves addressing the gaps between current competency and required competency, planning which involves setting of training objectives, selection of training methods, identification of trainer, duration of training, budgeting and setting monitoring and evaluation mechanism.

\subsubsection{Training Influence on Employees' Performance}

The study also sought to determine the influence of training on employees' performance at 


\section{Tanga UWASA}

The in-depth interview with respondents revealed that trainings which have been conducted at Tanga UWASA have influence on employees' performance. One of respondents had the following to say:

"Trainings that have been conducted in our organisation have made our organisation to be the best of all urban water authorities in Tanzania, we feel proud of that... the trainings improved performance of our employees, since equipped them with relevant skills and knowledge. Improvement of employees' performance led our authority to reduce non revenue water from $31 \%$ to $23 \%$, we have attained full cost recovery by $2013 / 2014$ and we have increased revenue collection form 2.6 billion by 2006/2007 to 8.96 billion by 2014/2015",

Moreover, respondents were provided with the table containing statements showing the influence of training on employees' performance. Respondents had to tick whether they agree, neutral or disagree to the statements provided. The results are presented on table 4 . below

Table 4. Perceived training influence on employees' performance

\begin{tabular}{llllll}
\hline Statements & $\begin{array}{l}\text { Strongly } \\
\text { Agree }\end{array}$ & Agree & Neutral & Disagree & $\begin{array}{l}\text { Strongly } \\
\text { disagreed }\end{array}$ \\
\hline $\begin{array}{l}\text { Training helped employees handle materials, } \\
\text { machines and equipment efficiently and thus }\end{array}$ & & 17 & 12 & 1 & 1 \\
$\begin{array}{l}\text { wastage of time and resource has been } \\
\text { avoided at Tanga UWASA }\end{array}$ & & & & \\
Trainings helped me to satisfy the customers & 35 & 15 & 14 & 5 & 2 \\
with quality services at Tanga UWASA \\
$\begin{array}{l}\text { Trainings increased organizational } \\
\text { performance at Tanga UWASA }\end{array}$
\end{tabular}

The findings in table 4. indicate that the overall performance of the respondents was $73.2 \%$ showing high performance, $16.9 \%$ medium and only 8.5 low performance. 
Table 5. Overall perceived influence of training on employee performance

\begin{tabular}{lll}
\hline Categories & $\mathrm{N}$ & \multicolumn{1}{c}{$\%$} \\
\hline High & 52 & 73.2 \\
Moderate & 12 & 16.9 \\
Low & 6 & 8.5 \\
Total & 71 & 100.0 \\
\hline
\end{tabular}

It is significant that majority $(86.2 \%)$ of the respondents receiving training have high perception on employee performance while few (7.7\%) of the respondents who did not receive training have high performance. The chi square shows that there is significant influence on receiving training and employee performance $(\chi 2=30.72 ; \mathrm{df}=2 ; \mathrm{p}=0.000)$. The correlation coefficient for receiving training and employee performance was 0.795, relationship is positive, which means that when the score of training increases the score of performance increase. This relationship was found statistically significant at $\mathrm{P}<0.05$. This implied that the receiving training increases the score of performance (Table 6).

Table 6. Influence of training on employee performance

\begin{tabular}{lllllllll}
\hline $\begin{array}{l}\text { Receiving } \\
\text { training }\end{array}$ & \multicolumn{2}{l}{ Level of employee performance } & & & \\
\hline & High & Medium & & Low & & Total \\
\hline & & $\%$ & $\mathrm{n}$ & $\%$ & $\mathrm{n}$ & $\%$ & $\mathrm{n}$ & $\%$ \\
\hline Yes & 48 & 82.8 & 8 & 13.8 & 2 & 3.4 & 58 & 81.7 \\
No & 3 & 23.1 & 2 & 15.4 & 8 & 61.5 & 13 & 18.3 \\
Total & $\mathbf{5 1}$ & $\mathbf{7 1 . 8}$ & $\mathbf{1 0}$ & $\mathbf{1 4 . 1}$ & $\mathbf{1 0}$ & $\mathbf{1 4 . 1}$ & $\mathbf{7 1}$ & $\mathbf{1 0 0 . 0}$ \\
\hline
\end{tabular}

$\chi 2=30.72 ; \mathrm{df}=2 ; \mathrm{p}=0.000 ; \mathrm{r}=0.628, \mathrm{p}=0.000$

These findings are in line with (Chang, 2002)'s study which revealed that trainings conducted at Taiwanese high technology firms had significant effect on employees' performance, also the studies by (Chiu, Luk \& Tang, 2002), (Tepstra \& Rozell,1993) and (Fey,Antonina,\& Ingmar, 2000) established that trainings and development has positive association with employees' performance. The findings imply that employees at Tanga UWASA have been enjoying job satisfaction, while the organisational performance at Tanga UWASA might have been improved. The same observation was done by (McKinsey, 2006) who argue that Employee training is important in any organization throughout the world, due to its active role in raising employee job satisfaction and improving organisational performance.

\section{Conclusion and Recommendation}

Basing on the findings for the research objective presented, analysed and discussed in this research work, the study concludes that training programmes that have been conducted and applied at Tanga UWASA have high influence on employees' performance. The correlation coefficient for receiving training and employee performance was positive. This positive influence has brought success to the authority on aspects such as; the rise of revenue collection, satisfaction of customers, effective use of time and other resources and attainment of full cost recovery.

Meanwhile based on findings the study recommends the following: 


\section{Macrothink Institute ${ }^{\mathrm{TM}}$}

- The management should improve the training programmes offered especially the use of study tours to other water supply authorities within and outside the country so that employees can learn how other authorities operate their day to day activities

- Training facilities should be improved and used according to the nature of employees and nature of the training programme conducted. This will help trainees to easily understand what they are taught hence it will facilitate effective transfer of the skills and knowledge to their working environment.

- The management should seek for enough funds which support the whole training process and after the training to provide enough facilities which the employees can use to transfer the knowledge and skills acquired from the training.

- Employees should be involved in the planning of training programmes. Their involvement may bring about innovation in the programmes and reduce their resistance in attending programmes which they think are not valuable to them.

\section{Areas for Further Study}

The study was conducted in public water supply and sewerage authority in the Tanga region. Further studies should be conducted in other authorities of the same nature so as to find out if their performance is influenced by training programmes or there are other factors. On the other hand, those studies should also focus on the reasons as to why most of the water supply and sewerage authorities underperform.

\section{References}

Appiah, B. (2010). The Impact of Training on Employee Performance. Unpublished Thesis, Ashesi University College.

Armstrong, M. (2006). A Handbook of Human Resources Management (10 ${ }^{\text {th }}$ ed). London: Ashford Colour press Ltd.

Aswathappa, K. (2014). Human Resources Management: Text and Cases. $7^{\text {th }}$ ed. New Delhi: McGraw Hill Education (India) Private Limited.

Benabou, C. (1996). Assessing the Impact of Training Programs on the Bottom Line. National Productivity Review, 15(3), 91-99. https://doi.org/10.1002/npr.4040150310

Bhatt, H., Pahwa, P., \& Ankona, B. (2013). Does Medical Training Promote or Deter Self-directed Learning? A longitudinal mixed-methods study. Journal of biomechanics: 88(11), 1754- 1764.

Chang, C. (2002). The Effect of Human Resources Management Practices on Firm Performance: Emprical evidence from High-Tech Firms in Taiwan. International Journal of Management.

Chiu, R. K., Luk, V. W., \& Tang, T. L. (2002). Retaining and Motivating employees: Compensation preferences in Hong Kong and China, Emerald insight. 
Clarke, N. (2004). HRD and the Challenges of Assessing Learning in the Workplace. International Journal of Training and Development. 8(2), 140-156. https://doi.org/10.1111/j.1468-2419.2004.00203.x

Creswell, J. W. (2003). Research Design: Qualitative,Quantitative and Mixed Approches,Second Edition.ThousandOaks: SAGE Publicatios..

DeCenzo, A. D., \& Robbins, P. S. (2000). Personnel / Human Resource Management (4 ${ }^{\text {th }}$ ed). New Delhi: Prentice-Hall.

Degraft, O. E. (2012). The Effect of Training and Development on Employee Performance at Accra Polytechnic. Unpublished MBA Thesis submitted to the Institute Of Distance Learning, Kwame Nkrumah University of Science and Technology.

Dessler, G. (2008). Human Resource Management. (11 ${ }^{\text {th }}$ ed). London: Pearson International Edition.

EWURA. (2014). Water Utilities Performance Review Report 2013/2014. [Online] Available http://144.76.33.232/wp-content/uploads/2015/04/ewura-water-regional-report-2014-final.pd

Fey, C. F., Antonia, P., \& Ingmar, B. (2000). The effect of Human Resources Management practices on firm performance in Russia. The International Journal of human Resources Management, 11(1), 1-18. https://doi.org/10.1080/095851900339963

Field, A. (2009). Discovering Statistics using SPSS( $3^{\text {rd }}$ ed), London, SAGE Publication Ltd

Glazier, J. D., \& Powel, R. R. (1992). Qualitative Research in Information Management, Englewood:Libraries Unlimited

Graham, H. T., \& Bennett, R. (1991). Human Resources Management (M \& E Handbook Series) Financial Times Prentice Hall.

Gray, R. (2004). How People Work and How you can help them to give their best. Tapei Prentice Hall, Finance Times.

Hamblin, A. C. (1974). Evaluation and Control of Training. London: McGraw-Hill.

Joshi, M. (2013). Human Resources Management .Bookboon.

McKinsey, Q. (2006). An Executive Take on the Top Business Trends. New York: McGraw-Hill.

Meyer, P. J., \& Smith, A. C. (2000). HRM Practices and Organisational Commitment: Test of Mediation Mode.s, Canadian Journal of Administrative Sciences, 17(4), 319-331. https://doi.org/10.1111/j.1936-4490.2000.tb00231.x

Mwambe, A. K. (2010). Influence of Training on Employees Performance in Higher Learning Institutions (CBE).

Nassazi, A. (2013).Effects of training on Employees Performance.Evidence from Uganda. Business Economics and Tourism. 


\section{Macrothink}

International Journal of Human Resource Studies

ISSN 2162-3058

2018, Vol. 8, No. 2

Ngirwa, C. A. (2009). Human Resource Management in African Work Organizations. Dar es Saalam: National Printing Co. Ltd.

Odinga, M. (2010). Staff Development Programs and Job Performance of Lecturers of Moi. [Online] Available makir.mak.ac.ug/handle/10570/2218?show=ful

Pallant, Y. (2011). SPSS Survival Manual: A Step by Step Guide to Data Analysis using SPSS for windows ( $3^{\text {rd }}$ ed).England: McGraw Hill: Open University Press.

Raja, A. G., Furqan, A. K., \& Muhammad, A. K. (2011). Impact of Training and Development on Organizational Performance. Global Journal of Management and Business Research, 11(7).

Reid, M. A., \& Barrington, H. (2003). Training Interventions: Promoting Learning Opportunities, (6th ed). London: CIPD.

Sekaran, U. (2007). Research Methods for Business, A skill Building Approach. India: Glorious Printer.

Tanga Urban Water Supply and Sewerage Authority. (2012) Strategic Plan.

Tanga Urban Water Supply and Sewerage Authority. (2012). Training and Development Policy. DSM: Government Printer.

Terpstra, D., \& Rozell, E. (1993).The Relationship of Staffing Practices to Organizational Level Measures of Performance. Personnel Psychology, 46, 27-48. https://doi.org/10.1111/j.1744-6570.1993.tb00866.x

URT. (2006). Water Sector Development Programme (2005 - 2025). DSM: Government Printer.

URT. (2013). Training Policy for the Tanzania Public Service. Dar Es Salaam: Government Printer.

Waziri, F., \& Stephen, T. (2013). Factors Influencing Implementation of Training Programme in Public Organizations in Tanzania. Developing Country Studies, 3(10), 94-99.

Wei, T. W. T. (2006). Effects of Training Framing, General Self-efficacy and Training Motivation on Trainees' Training Effectiveness. Emerald Group Publishers, 35(1), 51-65.

Winterton, J. C. (2007). Change in Knowledge of Midwives following Emergency Training: A randomized controlled trial of local hospitals,Simulation centre and team training. International Journal of Obstetrics and Gynaecology, 114(12).

\section{Copyright Disclaimer}

Copyright for this article is retained by the author(s), with first publication rights granted to the journal.

This is an open-access article distributed under the terms and conditions of the Creative Commons Attribution license (http://creativecommons.org/licenses/by/4.0/). 